\title{
UTILIZATION OF OZONE FOR THE IMPROVEMENT OF MENTHA PIPERITA L. QUALITY BY REDUCTION OF MICROBIAL LOAD AND IMPACT OF THE PROCESS ON THE HERB PROPERTIES
}

\author{
- Research paper -
}

\section{Piotr ANTOS*, Tomasz PIECHOWIAK ${ }^{* *}$, Krzysztof TERESZKIEWICZ* ${ }^{*}$, Maciej BALAWEJDER $^{1^{* *}}$}

\author{
* Department of Computer Science in Management, Faculty of Management, Rzeszów University of \\ Technology, al. Powstańców Warszawy 8, 35-959 Rzeszów \\ ** Departament of Chemistry and Food Toxicology, University of Rzeszów, Ćwiklińskiej 1, 35-601 \\ Rzeszów, Poland, phone: +48178721745
}

\begin{abstract}
Herbs can be contaminated with microorganisms, which affects their quality while increasing the risk of food poisoning. Thus, there is a need for efficient decontamination techniques. In this study, the microbial load was reduced in peppermint herb (Mentha piperita L.) exposed to ozone at $10 \mathrm{ppm}$ for 60 minutes. The quality of the ozonated herb was assessed by the determination of microbial load and essential oils content. Total microbial content was reduced by $4 \log \mathrm{cfu} \mathrm{g}^{-1}$ of the microorganisms whereas the contamination with molds was reduced from $10.07 \log \mathrm{cfu} \mathrm{g}^{-1}$ of the microorganisms to zero. Moreover, sensory evaluation of the herb aroma was conducted. These characteristics were not significantly affected by the treatment. Therefore, ozone can be used to improve the peppermint herb quality by reduction of the microbial contamination of peppermint herb while having no adverse effect on the herb aroma.
\end{abstract}

Keywords: quality management, ozone, herbs, essential oil content, microbial load

\section{INTRODUCTION}

Herbs are often used raw as spices, pharmaceutical or cosmetic products. Due to the limited shelf life of fresh herbs, they are often dried. However, due to the fact that spices in general are prepared from plants grown in tropical and subtropical regions with high humidity and temperatures, one can observe significant bacterial and fungal contamination; microbial loads as high as $10^{8} \mathrm{cfu}$ $\mathrm{g}^{-1}$, (colony forming unit per $1 \mathrm{~g}$ of the product) (Schweiggertet al., 2005; Akbas and Ozdemir 2008). Despite the fact that the easiest way to inactivate fungal and microbial activity is the reduction of water content, drying procedure is insufficient to deal with viable spores (Brodowska et al., 2014). Assessment of the microbial quality of raw plant resource requires the determination of presence/absence of pathogens e.g. Escherichia coli, Salmonella, Shigella spp, Listeria monocytogenes, etc., that cause food poisoning.

Received: 10.05.2020.

Accepted in revised form: 20.08.2020

${ }^{1}$ Corresponding author. E-Mail address: maciejb@ur.edu.pl
The amount of non-pathogenic microorganisms should also be determined because they can be responsible for the deterioration of sensory attributes of the product (Doğan and Gürler 2018). The microbial contamination is mainly a result of the exposition of different plant parts with external environment during cultivation and the plant susceptibility to infections during drying and storage (Song et al., 2014). Moreover, microbial contamination of herbs depends on which parts of the plant undergo processing.

The microflora of the plant material may also depend on its origin due to the presence of microorganisms naturally inhabiting plants (epiphytic microflora) and the environmental pollution (soil, water or air) (Brodowska et al., 2014). Epiphytic microflora is predominantly Gram-negative bacteria belonging to the genera Pseudomonas, Enterobacter, Flavobacterium, Alcaligenes, Aerobacter, Chromobacaterium, Spirillum. The group of Gram-positive bacilli include spore of Bacillus, whereas the typical 
molds belong to the genera of Alternaria, Fusarium, Cladosporium, Penicillium (KunickaStyczyńska and Smigielski, 2011). According to the studies reported by (Wójcik-Stopczyńska et al., 2009), the herbal spices that are available on the Polish market, contain a high number of mesophilic bacteria, e.g., up to to $6 \log \mathrm{cfu} \mathrm{g}^{-1}$, and thermophilic bacteria up to $5.18 \log \mathrm{cfu} \mathrm{g}^{-1}$. Bacterial contamination varies greatly, which depends on the type of herb and manufacturer (Wójcik-Stopczyńska et al., 2009).

Decontamination techniques should enable the inactivation of various pathogens, while having none, or only a marginal impact on the product quality. The concentration of essential oils, that is a key element for determination of the quality of herbal resource, can change during the herb treatment with procedures involving water vapor. Ozone is a powerful oxidant, that is well known for its antimicrobial activity (Akbas and Ozdemir 2008; Alexopoulos et al., 2013; Alwi and Ali, 2014; Khadre et al., 2001; Smilanick, 2003; Sung et al., 2014; Torlak et al., 2013; Wani et al., 2015; Wysok et al., 2006). However, utilization of oxidants such as ozone may pose a potential threat to the terpenes contained in the volatile fraction of spices, such as black pepper (Zhao and Cranston, 1995) and other.

The composition of essential oils and their content is a very important parameter determining the quality of peppermint (Mentha piperita L.). The quality of the herb can be assesed based on the Essential oils content inside the herb, which is around $3 \% \mathrm{w} / \mathrm{w}$. Some compounds contained in the essential oils fraction in peppermint herb are: $\alpha$ pinene, $\beta$-pinene, menthone, menthol, carane, $\beta$ burbonen, $\quad \beta$-caryophyllene, germacrene-D (Adaszyńska et al., 2013). Terpenes that are the basic components of essential oils are susceptible to degradation by ozone molecules, e.g., dlimonene, $\alpha$-terpinene and $\alpha$-pinene were reported to be degraded by ozone molecules present indoors (Kephalopoulos et al., 2007; Weschler and Shields, 1999) . Other properties, as colour of spice can also be affected (Brodowska et al., 2014).

The most sensitive tool for the evaluation of the peppermint quality is smell. Very often, variations of sensory properties occur for food components even though they do not differ in other properties determined by instrumental analysis. The goal of this research was to improve the quality of the pepper mint herb using ozone by reduction in microbial load while preserving standard properties of the plant. To determine the impact of gaseous ozone on the properties of treated herb, the analysis of essential oils content and its composition, moisture content, $\mathrm{pH}$ of infusions and the sensory analysis of aroma of the essential oils and infusions prepared from peppermint prior and after ozone treatment were performed.

\section{Decontamination procedure}

The peppermint herb was placed into the reactor chamber of the device (Figure 1) that has already been successfully utilized for various detoxication procedures (Balawejder et al., 2014).

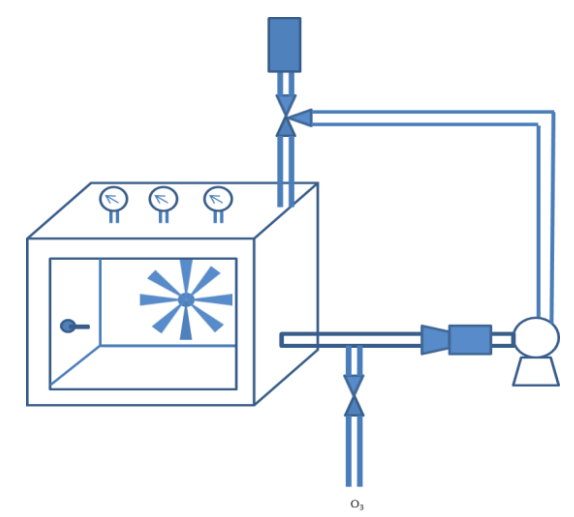

Figure 1. Scheme of the apparatus used for the ozone treatment of herbs

In our previous studies it was determined that optimal time of living plant ozonation should not 
exceed 30 minutes. After that time on the investigated plant organisms necrosis was observed. In the case of dried plant material this time was twicefold increased witout such concseqencies. Shorter exposition times (Piechowiak et al., 2019a; 2019b) allowed satisfactionary effects during the treatement of raspberry and highbush blueberry fruits. But in a case of dried plants a resistance spores could be observed, therefore we decided to increased ozonation time. Longer exposure than $60 \mathrm{~min}$ would be not optimal in terms of technological procedures and economical effectiveness.

Samples $(\sim 100 \mathrm{~g})$ of the herb were exposed to ozone at the concentration of $10 \mathrm{ppm}$ for $60 \mathrm{~min}$ with the gas-flow rate of $4 \mathrm{~m}^{3} \mathrm{~h}^{-1}$ at room temperature. Prior and after the ozone treatment, a number of parameters, including: the microbial load, moisture content, sensory properties, content and composition of essentials oils were determined. The experiments were conducted in triplicate.

\section{Preparation of the substrates and cultivation of microorganisms}

The microbial cultures were prepared by mixing $1 \mathrm{~g}$ peppermint before and after the ozonation and drying procedure with $9 \mathrm{~mL}$ of sterile physiological solution. Then, the sample was gradually diluted to achieve a concentration of $10^{-7}$ $\mathrm{g} / \mathrm{mL}$.

The microbiological media were prepared as follows: Czapek solution agar (BTL Łodź Poland) $50 \mathrm{~g}$ of the powder per $1000 \mathrm{~mL}$ of water and Nutrient Agar (BTL Lodź Poland) 38g of the powder per $1000 \mathrm{~mL}$ of water. Subsequently, those solutions were boiled and stirred for $15 \mathrm{~min}$. Then, the media were cooled down and transferred into Petrie dishes (approximately $15 \mathrm{~mL}$ per dish).

After solidification of the media, a $0.1 \mathrm{~mL}$ sample of the solution containing bacteria was transferred into the Petrie dishes using the surface spread plate method. Prior and after each transfer, the spreader was treated by $70 \%$ solution of ethanol (Chempur Piekary Śląskie Poland) and heated up over the flame. Incubation was conducted under following conditions: Nutrient Agar $35^{\circ} \mathrm{C} 48 \mathrm{~h}^{-1}$, Czapek solution agar $25^{\circ} \mathrm{C} 24 \mathrm{~h}^{-1}$. The latter is suitable for cultivation of molds, which presence is undesired due to production of mycotoxins.

\section{Composition of the essentials oils}

The analysis of the composition of the essentials oils in the dried peppermint was performed using a Deryng type apparatus. For this purpose, a round bottom flask was filled with $50 \mathrm{~g}$ of the peppermint and $400 \mathrm{~mL}$ of distilled water. Distillation was conducted for 1 hour (after one hour the volume of essential oil was constant), and as soon as it was accomplished, the mixture was cooled down for 30 minutes. Subsequently, the essential oils that were collected during this procedure, were dried over anhydrous magnesium sulfate and subjected to chromatographic analysis. The analysis was conducted using a Varian GC-450 gas chromatograph coupled with a MS-240 mass spectrometer. The separation of analytics was done on a capillary column Varian, (Palo Alto California USA) L(m) $x$ ID $(\mathrm{mm}) \times$ OD $(\mathrm{mm})-30 \times 0.25 \times$ 0.25 . The stationary phase was VF- $5 \mathrm{~ms}$, film thickness $(\mu \mathrm{m}): 0.25$. The settings of the analysis were: the temperature of injector $200{ }^{\circ} \mathrm{C}$, the sample volume $1 \mu \mathrm{l}$, split $1: 100$, the column oven start $50{ }^{\circ} \mathrm{C}$ for $1 \mathrm{~min}$, gradient $300{ }^{\circ} \mathrm{C} 10 \mathrm{~min}^{-1}, 20$ minute isothermally. The gas flow rate was $1 \mathrm{ml}$ $\min ^{-1}$ (He purity 5.0).

\section{Essential oils content and composition}

In order to verify the impact of ozone on the essential oil content and composition, the essential oils were isolated using Deryng apparatus. The analysis of the essential oils content prior and after the ozonation procedure allowed determination of possible losses of the essential oils. The calculation of their content within the peppermint herb was done according to equation 1 :

essential oil content $=\frac{a \times 100 \%}{b}$

where:

a - volume of essential oil $\left[\mathrm{cm}^{3}\right]$,

$\mathrm{b}$ - mass of the pepper mint sample [g].

The calculation based on this formula allowed determining the percentage of the essential oils in pepper mint prior and after the ozonation process which was $1.24 \% \pm 0.21$ and $1.28 \% \pm 0,07$ respectively. The analysis showed no statistically significant differences in the average content of essential oils at the significance level $\alpha=0.05$ between the two experiments.

\section{Composition of the volatile fraction}

The volatile faction of peppermint was analyzed using HS-SPME method with a PDMS fiber thickness $100 \mu \mathrm{m}$ (Supelco Pennsylvania USA). The PDMS fiber was exposed to volatile fraction of peppermint herb for 30 minutes by placing the fiber over the herbal material. Then, the fiber was placed into the injector for 5 minutes. The settings of the chromatographic analysis were: exposition time of the solid phase: start $50{ }^{\circ} \mathrm{C} 5 \mathrm{~min}^{-1}$, gradient $250{ }^{\circ} \mathrm{C}$ in $10 \mathrm{~min}^{-1}, \quad 10$ minutes isothermally, temperature decrease to $30^{\circ} \mathrm{C}$ 
$\left(20{ }^{\circ} \mathrm{C} \mathrm{min}^{-1}\right) 5$ minute isothermally. The gas flow rate was $1 \mathrm{ml} \mathrm{min}^{-1}(\mathrm{He})$.

\section{Determination of the moisture content}

The moisture content in peppermint herb was determined using a moisture analyzer RADWAG MAX 50/1. The maximal temperature during this procedure was $105^{\circ} \mathrm{C}$.

\section{Determination of acidity and $\mathrm{pH}$ of the peppermint infusion}

The solutions of the peppermint herb were prepared by mixing $1 \mathrm{~g}$ of the product and $50 \mathrm{~mL}$ of boiled distilled water. After 20 minutes, the infusions were transferred through a filter into a $200 \mathrm{~mL}$ flask and filled up with distilled water. Acidity was determined by titration of $25 \mathrm{~mL}$ of the prepared solution with $0.01 \mathrm{NaOH}$ versus phenolphthalein as indicator. $\mathrm{pH}$ was measured with a CP-315 pH-meter.

\section{RESULTS AND DISCUSSION}

\section{Changes of the microbial load as a result of the ozonation procedure}

In our study, Czapek solution agar and Nutrient Agar substrates were utilized. The number of the microorganisms in the peppermint herb was calculated for $1 \mathrm{~g}$ of the product and presented as $\log \mathrm{cfu} \mathrm{g}^{-1}$.

It was observed that the ozone treatment was effective in inactivation of the microorganisms, in particular molds, which can be grown on Czapek solution agar substrate. On that substrate an initial number of $10.07 \mathrm{log}_{\mathrm{cfu} \mathrm{g}} \mathrm{g}^{-1}$ of the microorganisms was detected, whereas after the ozonation procedure no microorganisms were cultivated.

The ozone treatment at the ozone concentration of $10 \mathrm{ppm}$ resulted in decontamination of peppermint herb from molds. This is very important observation due to the fact that absence of molds can stop the generation of mycotoxins that are products of the mold metabolism. The presence of mycotoxins can cause the ban of the utilization of contaminated plant material.

In case of microorganisms growable on the Nutreient Agar medium, it was shown that ozonation allowed reduction in the total microbial load from 12 to $8 \log \mathrm{cfu} \mathrm{g}^{-1}$. Prior to the ozonation procedure, a number of colonies of different colours was observed. After the ozonation process the colonies colour was white, they had uniform shape and clearly marked edges of the colony.

\section{Sensory analysis}

The impact of the ozonation procedure on the quality of the peppermint sensory quality was determined by analyzing responses to a questionnaire that included following questions: attractiveness and intensity of the infusion smell, attractiveness and intensity of the essential oil smell, before and after ozonation. The quantity of the respondents group was 40 tutored people. The portions of $5 \mathrm{~mL}$ of essential oils and infusions prepared from $1 \mathrm{~g}$ of product and $50 \mathrm{~mL}$ of water were coded and presented to respondents and rated using a five grade scale. The aroma attractiveness and the intensity of aroma of coded samples of the essential oils and the infusions were rated as follows: 1-very weak/bad, 2-weak, 3-average, 4good, 5-very well. Sensory analysis was conducted according to PN-ISO 4121:1998 - Polish version. The statistical analyzes were conducted using Statistica 13 (StatSoft Poland).

These colonies presumably arose from spore forms that had an increased resistance to disinfectants. Other researchers also observed the positive impact of ozonation procedures on the reduction of microbiacl load of microorganisms belonging to various species. The reduction of the the microorganisms belonging to Enterobacteriaceae ( 2 to $3 \log \mathrm{cfu} \mathrm{g}^{-1}$ ) was observed by (Achen and Yousef, 2001) who observed reduction in E. coli for over $3 \log \mathrm{cfu} / \mathrm{g}$ during utilization of ozonated water with ozone concentration of $25 \mathrm{mg} \mathrm{L}^{-1}$ and 5 minutes long exposure for decontamination of apples. Also, Akbas and Ozdemir in 2008 utilized gaseous ozone at concentration of up to $1 \mathrm{ppm}$ for decontamination of flaked red pepper. Only a marginal effect on the $E$. coli population was observed e.g., reduction of $1 \log \mathrm{cfu} \mathrm{g}^{-1}$ of the initial population (Akbas and Ozdemir, 2008). Similar results were also observed during ozonation of spinach at $1 \mathrm{ppm}$ for 10 minutes (1 log cfu/g reduction) (Wani et al., 2015). However, at a higher ozone concentration (10-50 ppm) over $1 \log$ cfu $\mathrm{g}^{-1}$ reduction was observed (Wani et al., 2015). Also, the reduction of the $E$ coli counts for about $3 \mathrm{log} \mathrm{cfu} / \mathrm{g}$ in lettuce and green bell pepper was achieved using ozonated water at ozone concentration of $0.5 \mathrm{mg} / \mathrm{L}$ after 30 $\mathrm{min}^{-1}$ of washing (Alexopoulos et al., 2013). In another research Alwi and Ali in 2014 observed reduction of E coli O157 and Salmonella enterica sv. typhimurium counts for about 1-2 $\log \mathrm{cfu} \mathrm{g}^{-1}$ after exposing bell pepper to ozone at concentrations ranged from $0.5 \mathrm{ppm}$ up to $9 \mathrm{ppm}$ (Alwi and Ali., 2014). 
Ozonation was also utilized for the reduction of the microbial load on oregano where after 90 minutes of ozonation the counts of Salmonella typhimurium were reduced by $1.88 \log$ at $2.8 \mathrm{ppm}$ and by $2.5 \mathrm{log}$ at $5.3 \mathrm{ppm}$. A longer exposition of oregano to ozone (e.g., for 120 minutes) resulted in higher reduction in the counts of Salmonella by $2.8 \mathrm{log}$ $\mathrm{cfu} \mathrm{g}^{-1}$ at $2.8 \mathrm{ppm}$ and $3.7 \mathrm{log} \mathrm{cfu} \mathrm{g}^{-1}$ at $5.3 \mathrm{ppm}$ (Torlak et al., 2013). It should be noticed that detection of pathogens should result in elimination of contaminated plant material.

\section{Essential oils composition}

The composition of the essential oils was determined based on the analysis of chromatograms (see Figure 2), using NIST8 (Mass Spectra Library) and CAS (Chemical Abstracts
Service). All of the detectable compounds were summarized in Table 1. As it can be observed, the analytical procedure allowed identification of the compounds expected to be found within the essential oils fraction in peppermint herb, such as: $\alpha$-pinene, $\beta$-pinene, menthone, menthol, carane, $\beta$ burbonen, $\quad \beta$-caryophyllene, germacrene-D (Adaszyńska et al., 2013) (Table 1). It could be anticipated that some of those essential oils and in particular those that have a double bond within their chemical structure, may undergo degradation due to ozone oxidative potential. However, the data acquired by the chromatographic analysis showed that the essential oils composition is similar for the control and ozonated peppermint samples.



Figure 2. Chromatograms of the Essentials oil before and after the ozonation procedure

Table 1. Composition of the essential oils of the peppermint herb prior and after exposure to ozone

\begin{tabular}{|c|c|c|c|}
\hline $\begin{array}{l}\text { Retention time } \\
\text { [min] }\end{array}$ & Compound name & $\begin{array}{c}\text { Content before } \\
\text { ozonation } \%\end{array}$ & $\begin{array}{l}\text { Content after } \\
\text { ozonation } \%\end{array}$ \\
\hline 5.48 & $\alpha$-Pinene & Trace & trace \\
\hline 6.11 & 3-Carene & Trace & trace \\
\hline 6.24 & $\beta$-Pinene & Trace & trace \\
\hline 7.11 & Eucalyptol & $2.48 \%$ & $4.81 \%$ \\
\hline 9.08 & (E)-Menthone & $45.62 \%$ & $39.99 \%$ \\
\hline 9.17 & (Z)-Menthone & $9.23 \%$ & $9.65 \%$ \\
\hline 9.23 & Neomenthol & $3.15 \%$ & $3.33 \%$ \\
\hline 9.35 & Menthol & $28.39 \%$ & $32.34 \%$ \\
\hline 9.57 & L-Menthol & Trace & Trace \\
\hline 10.27 & Pulegone & Trace & Trace \\
\hline 10.54 & Piperitone & Trace & $0.73 \%$ \\
\hline 10.69 & m-Menth-3(8)-ene & Trace & Trace \\
\hline 10.88 & Carane & $8.75 \%$ & $8.70 \%$ \\
\hline 11.16 & Cyclohexene, 3-methyl-6-(1-methylethyl) & Trace & Trace \\
\hline 12.30 & $\beta$-Bourbonene & Trace & Trace \\
\hline 12.80 & $\beta$-Caryophyllene & $0.89 \%$ & Trace \\
\hline 13.28 & $\alpha$-Caryophyllene & Trace & Trace \\
\hline 13.37 & $\beta$-Cububene & Trace & Trace \\
\hline 13.61 & (E)-Germacrene-D & $0.96 \%$ & Trace \\
\hline
\end{tabular}




\section{Comparison of the volatile fraction}

Although no differences in the composition of the essential oils contained in the ozonated peppermint herb were observed, ozone could have still impact on the volatile fraction. The volatile fraction of the peppermint contains compounds that are responsible for smell of the herb. That trait is highly valued by potential consumers. Therefore, the composition of volatile fraction prior and after ozonation was analyzed using the HS-SPME method. That sampling technique involves the utilization of a fiber coated with the extracting phase (polymer or sorbent). It enables extraction of various substances from liquid or gaseous phases. This method allows determination of the presence of volatile organic compounds with high vapor pressure. These compounds can be generated in the process of decomposition of essential oil components. As ozone acts mainly on the surface, these compounds should potentially be also on the surface of ozonated plant material. HS-SPME analysis is expected to reveal their presence. All of the identified compounds are summarized in table 2 (see Table 2). Analogously to the essential oils content, the volatile fraction content was determined based on the analysis of chromatograms (Figure 3) using NIST8 (Mass Spectra Library) and CAS (Chemical Abstracts Service). Just like in the case of the essential oils composition, the analysis of the composition of the volatile fraction showed that the composition of the volatile fraction prior to and after ozonation was similar. The lack of significant differences proves that the applied ozone dose did not affect the composition of the head space of ozonated material. However, sensory analysis can often detect differences in odor that cannot be detected by instrumental methods. Therefore, the next step was a sensory analysis of the ozonated mint and the control sample.

\section{Moisture content of the peppermint herb}

We expected that ozonation could induct the drying process, where peppermint herb was exposed on the gaseous stream for 60 minutes, might cause a mass loss. As we find out, the presence of ozone had negligible impact on the weight and moisture of the peppermint samples e.g., $-10 \%$ of moisture content after ozonation and $12 \%$ without ozonation.

\section{Acidity and the $\mathrm{pH}$ value of the peppermint infusion prior and after the ozonation procedure}

Acidity was determined using titration of the peppermint infusions with sodium hydroxide and the $\mathrm{pH}$ value was measured prior and after 20 minutes of the brew. It was observed that the acidity of the infusion was constant throughout the experiment, however the $\mathrm{pH}$ of the infusion was slightly reduced (see Table 3 ).

\section{Sensory assessment of the organoleptic properties}

To assess the sensory quality of the herb prior and after the ozonation, a group of 40 consumers was asked about the perception of aroma attractiveness and intensity of the essential oils and the peppermint infusions. The results of the analysis are reported in Table 4. The statistical analysis based on the test of statistical significance of the difference between two means revealed that at the significance level $\alpha=0.05$ no difference between the attractiveness and intensity of the assessed oils and infusions was found. This clearly confirms that the ozonation procedure had no negative impact on the sensory quality of the peppermint.

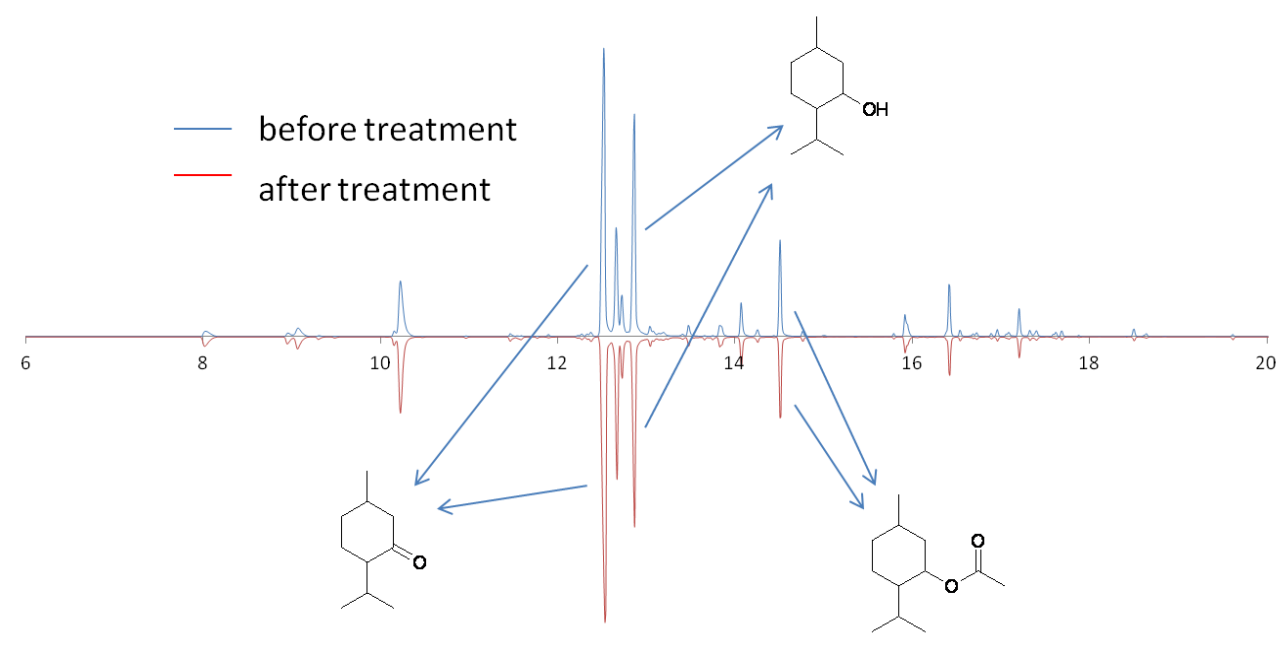

Figure 3. Chromatogram of the volatile fraction of the peppermint herb before and after ozonation procedure 
Table 2. Composition of the volatile compounds of the peppermint herb prior and after exposure to ozone

\begin{tabular}{|c|c|c|c|}
\hline Retention time [min] & Compound & $\begin{array}{c}\text { Content before } \\
\text { ozonation } \%\end{array}$ & $\begin{array}{l}\text { Content after } \\
\text { ozonation \% }\end{array}$ \\
\hline 8.12 & $\alpha$-Pinen & Trace & trace \\
\hline 8.42 & Camphene & Trace & 0.002 \\
\hline 8.94 & $\beta$-terpinene & Trace & 0.85 \\
\hline 9.06 & 2-Thujene & 1.613 & 1.799 \\
\hline 9.30 & Bicyclo [3.1.1]heptane & 0.137 & 1.273 \\
\hline 10.15 & S-(-)-Limonene & 0.4 & 0.709 \\
\hline 10.22 & Eucalyptol & 7.654 & 8.987 \\
\hline 10.46 & 3-Carene & 0.01 & 0.04 \\
\hline 10.96 & Trans-para-2-menthen & 0.076 & 0.116 \\
\hline 11.46 & Linalool & 0.423 & 0.423 \\
\hline 12.37 & (-)-Isopulegol & 0.387 & 0.44 \\
\hline 12.52 & (E)-Menthone & 26.932 & 31,160 \\
\hline 12.66 & (Z)-Menthone & 8.968 & 10.633 \\
\hline 12.86 & Menthol & 20.081 & 17.345 \\
\hline 13.47 & 1-n-Propylcyclohexanol & 0.883 & 0.667 \\
\hline 13.82 & Pulegone & 1.308 & 1.1088 \\
\hline 14.07 & Piperitone & 2.424 & 2.075 \\
\hline 14.51 & Menthyl Acetate & 7.495 & 6.201 \\
\hline 15.91 & $\beta$-bourbobene & 2.462 & 1.648 \\
\hline 16.42 & $\beta$-Caryophyllene & 4.454 & 2.715 \\
\hline 17.20 & Beta-cububene & 1.928 & 1.402 \\
\hline 18.50 & Caryophyllene oxide & 0.544 & trace \\
\hline
\end{tabular}

Table 3. Determination of the acidity and the $\mathrm{pH}$ of the peppermint infusions prior and after the exposition of the peppermint drought to ozone enriched atmosphere

\begin{tabular}{|c|c|c|c|}
\hline & Time of brew & Acidity & $\mathrm{pH}$ value \\
\hline \multirow[t]{2}{*}{ Before ozonation } & 10 minutes & $0.3 \mathrm{~mL} 0.01 \mathrm{M} \mathrm{NaOH}$ & 6.63 \\
\hline & 20 minutes & $0.3 \mathrm{~mL} 0.01 \mathrm{M} \mathrm{NaOH}$ & 6.64 \\
\hline \multirow[t]{2}{*}{ After ozonation } & 10 minutes & $0.3 \mathrm{~mL} 0.01 \mathrm{M} \mathrm{NaOH}$ & 6.45 \\
\hline & 20 minutes & $0.3 \mathrm{~mL} 0.01 \mathrm{M} \mathrm{NaOH}$ & 6.47 \\
\hline
\end{tabular}

Table 4. Determination of sensory properties of the essential oils and peppermint drought infusions

\begin{tabular}{cccc}
\hline \multicolumn{2}{c}{ Assesed properties } & Average & Standard deviation \\
\hline \multirow{2}{*}{$\begin{array}{c}\text { Attractiveness of the essentials } \\
\text { oil aroma }\end{array}$} & before ozonation & 3.800 & 0.759 \\
\cline { 2 - 4 } $\begin{array}{c}\text { Intensity of the essentials oil } \\
\text { aroma }\end{array}$ & after ozonation & 3.875 & 0.719 \\
\cline { 2 - 4 } $\begin{array}{c}\text { Attractiveness of the infusion } \\
\text { aroma }\end{array}$ & before ozonation & 4.025 & 0.797 \\
\cline { 2 - 4 } $\begin{array}{c}\text { Intensity of the infusuion } \\
\text { aroma }\end{array}$ & after ozonation & 3.850 & 0.792 \\
\hline & before ozonation & 3.750 & 0.653 \\
\hline
\end{tabular}

\section{CONCLUSIONS}

The exposure of the peppermint herb to ozone enriched atmosphere resulted in reduction in various microorganisms including molds and total aerobic microorganisms.

Moreover, it had no effect on the moisture content of the peppermint drought. Also, acidity of the infusions prepared from herb did not change during ozonation process. $\mathrm{pH}$ of the peppermint infusion decreased slightly as a result of ozonation. No difference in the essential oils content prior and after the ozonation procedure was found at the significance of $\alpha=0.05$.

The chromatographic methods allowed determination of the composition of the essential oils and volatile fraction in the peppermint herb. The chemical analysis was supplemented by a 
sensory assay based on the responses of 40 consumers. At the significance level of $\alpha=0.05$ no differences within the essential oils or the peppermint infusion aroma and its intensity prior and after the ozonation procedure were found. Therefore, it was possible to improve the quality of peppermint herb by means of ozonation without adverse effects on other parameters of the herb.

\section{REFERENCES}

1. Achen, M., Yousef, A.E. (2001). Efficacy of Ozone Against Escherichia coli O157:H7 on Apples. Journal Of Food Science 66 (9), 1380-1385.

2. Adaszyńska, M., Swarewicz, M., Markowska, A., Szczupak, A., Jadczak, D. (2013). Skład chemiczny i właściwości przeciwdrobnoustrojowe olejku eterycznego i ekstraktu z mięty pieprzowej odmiany 'Asia'. Żywność. Nauka. Technologia. Jakość, 2 (87), 116-125.

3. Akbas, M.Y., Ozdemir, M. (2008). Effect of gaseous ozone on microbial inactivation and sensory of flaked red pepper. International Journal of Food Science and Technology, 43, 1657-1662 DOI: 10.1111/j.1365-2621.2008.01722.x

4. Alexopoulos, A., Plessas, S., Ceciu, S., Lazar, V., Mantzourani, I., Voidarou, C., Stavropoulou, E., Bezirtzoglou, E. (2013). Evaluation of ozone efficacy on the reduction of microbial population of fresh cut lettuce (Lactuca sativa) and green bell pepper (Capsicum annuum). Food Control 30, 491-496 http://dx.doi.org/10.1016/j.foodcont.2012.09.018

5. Alwi, N.A., Ali, A. (2014). Reduction of Escherichia coli O157, Listeria monocytogenes and Salmonella enterica sv. Typhimurium populations on fresh-cut bell pepper using gaseous ozone. Food Control, 46, 304-311.

6. Balawejder, M., Szpyrka, E., Antos, P., Józewczyk, R., Piechowicz, B., Sadło, S. (2014). Method for Reduction of Pesticide Residue Levels in Raspberry and Blackcurrant Based on Utilization of Ozone. Ochrona Srodowiska i Zasobów Naturalnych, 25 (4), 1-5. 10.2478/oszn-2014-0018

7. Brodowska, A., Śmigielski, K., Nowak, A. (2014). Comparison of methods of herbs and spices decontamination. Chemik, 68, 87-102.

8. Doğan Y. \& Gürler Z. (2018). The effect of natural microbiota on colour, texture and sensory properties of sucuk during the production. Ankara Universitesi Veteriner Fakultesi Dergisi. 65. 137-143. 10.1501/Vetfak_0000002839.

9. Khadre, M.A., Yousel, A.E., Kim, J.G. (2001). Microbiological Aspects of Ozone Applications in food a Review. Journal of Food Science, 66 (9), 1242-1250.

10. Kunicka-Styczyńska, A., Śmigielski, K. (2011). Microbiological safety of herbal raw materials. In Polish Przemyst spożywczy, 65 (6), 50-53.

11. Kephalopoulos, S., Kotzias, D., Koistinen, K. (2007). Impact of Ozone-initiated Terpene Chemistry on Indoor Air Quality and Human Health" European Commission Joint Research Centre - Institute for Health \& Consumer Protection, Physical \& Chemical Exposure Unit Report No 26, http://www.inive.org/medias/ECA/ECA_Report26.pdf accessed 11.10.2019

12. Piechowiak, T., Antos, P., Kosowski, P., Skrobacz, K., Józefczyk, R., \& Balawejder, M. (2019a). Impact of ozonation process on the microbiological and antioxidant status of raspberry (Rubus ideaeus L.) fruit during storage at room temperature. Agricultural and Food Science, 28 (1), 35-44. https://doi.org/10.23986/afsci.70291

13. Piechowiak T., Antos P., Józefczyk R., Kosowski P., Skrobacz K. \& Balawejder M. ( 2019b). Impact of Ozonation Process on the Microbiological Contamination and Antioxidant Capacity of Highbush Blueberry (Vaccinum corymbosum L.) Fruit during Cold Storage. Ozone: Science \& Engineering, 41(4) https://doi.org/10.1080/01919512.2018.1540922

14. Schweiggert, U., Mix, K., Schieber, A., Carle, R. (2005). An innovative process for the production of spices through immediate thermal treatment of the plant material. Innovative Food Science and Emerging Technologies 6, 143-153. http://dx.doi.org/10.1016/j.ifset.2004.11.006

15. Smilanick JL. Use of ozone in storage and packing facilities. Washington Tree Fruit Postharvest Conference, WSU-TFREC Postharvest Information Network 2003; 1-10, Electronic source address: http://postharvest.tfrec.wsu.edu/PC2003H.pdf

16. Song. W.J., Sung, H.J., Kim, S.Y., Kim, K.P., Ryu, S., Kang, D.H. (2014). Inactivation of Escherichia coli O157:H7 and Salmonella Typhimurium in black pepper and red pepper by gamma irradiation. 
$\begin{array}{llll}\text { International Journal of } \quad \text { Food } & \text { Microbiology, } & 172, & 125-129 .\end{array}$ http://dx.doi.org/10.1016/j.ijfoodmicro.2013.11.017

17. Steinka, I., Misiewicz, Ł., Kukułowicz, A., Ćwikliński, M., Dmowski, P., Sznajdrowska, A. (2011), Próba oceny jakości mikrobiologicznej wybranych suszy roślinnych stosowanych jako używki i preparaty o znaczeniu leczniczym. Akadaemia Morska w Gdyni, 68, 13-20.

18. Sung, H.J., Song, W.J., Kim, K.P., Ryu, S., Kang, D.H. (2014). Combination effect of ozone and heat treatments for the inactivation of Escherichia coli O157:H7, Salmonella Typhimurium, and Listeria monocytogenes in apple juice. International Journal of Food Microbiology, 171, 147-153. http://dx.doi.org/10.1016/j.ijfoodmicro.2013.11.001

19. Torlak, E., Sert, D., Ulca, P. (2013). Efficacy of gaseous ozone against Salmonella and microbial population on dried oregano. International Journal of Food Microbiology, 165, 276-280. http://dx.doi.org/10.1016/j.ijfoodmicro.2013.05.030

20. Wani, S., Maker, J.K., Thompson, J.R., Barnes, J., Singleton, I. (2015). Effect of Ozone Treatment on Inactivation of Escherichia coli and Listeria sp. on spinach. Agriculture, 5, 155169.10.3390/agriculture5020155

21. Weschler, C.J., Shields, H.C. (1999). Indoor ozone/terpene reactions as a source of indoor particles. Atmospheric Environment, 33, 2301-2312.http://dx.doi.org/10.1016/S1352-2310(99)00083-7

22. Wójcik-Stopczyńska, B., Jakubowska, B., Reichert, M. (2009). Microbiological contamination of dried culinary herbs. Herba Polonica, 3 (55), 206-213. http://dx.doi.org/10.1016/j.foodcont.2014.05.037

23. Wysok, B., Uradziński, J., Gomólka-Pawlicka, M. (2006). Ozone as an alternative disinfectant - a Review. Polish Journal of Food and Nutrition Sciences, 15 (56), 3-8.

24. Zhao, J., Cranston, P.M. (1995). Microbial decontamination of black pepper by ozone and the effect of the treatment on volatile oil constituents of the spice. Journal Of the Science of Food and Agriculture, 68,11-18. doi: $10.1002 /$ jfa. 2740680103 